\title{
Teat Length and Lactation Period as A Predisposition Factor of Subclinical Mastitis in Dairy Cattle in Bandung, Indonesia
}

\author{
Herwin Pisestyani ${ }^{1}$, RP Agus Lelana ${ }^{2}$ and Yeti Nevia Septiani ${ }^{2}$ \\ 1. Veterinary Public Health Division, Department of Animal Health and Veterinary Public Health, Faculty of Veterinary Medicine, \\ Bogor Agricultural University, Bogor 16680, Indonesia \\ 2. Clinic Division, Department of Clinic Reproduction and Pathology, Faculty of Veterinary Medicine, Bogor Agricultural \\ University, Bogor 16680, Indonesia
}

\begin{abstract}
In order to improve the practical approach to clinical diagnosis of subclinical mastitis, 72 dairy cattle from KPSBU Lembang Bandung Regency was used in this research. The purpose of this research was to study the correlation between udder length and lactation period with the profile of subclinical mastitis. Lactation period data was collected from interviews with farmers. Subclinical mastitis testing by IPB-1 Mastitis Test reagent and udder length measured using measuring tape $(\mathrm{cm})$. Data was analyzed using Duncan test and logistic regression. The highest correlation of subclinical mastitis occurred to dairy cattle with average udder length of $7.5 \mathrm{~cm}$ and was in the third and forth lactation period. This result shows that udder length and lactation period of dairy cattle is a predisposing factor for subclinical mastitis. This finding is important to improve the milking management as well as a way to diagnose subclinical mastitis.
\end{abstract}

Key words: Lactation period, subclinical mastitis, udder length.

\section{Introduction}

Subclinical mastitis is a disease in dairy cattle that has not been handled well. Subclinical mastitis is inflammation of the internal tissue of the udder [1]. Losses caused by subclinical mastitis are decreased in milk production, decreased of milk quality, expensive cost for treatment and medication, early culling of cattle as well as purchasing of new dairy cattle [2]. These threats are faced by 127,211 farmers in Indonesia whose cattle population reached 475 thousand heads with 19 million liter of milk production [3]. It will be hard for Indonesia to reach self-sufficiency in milk if it does not pay attention to these threats are. Indonesia is currently only able to fulfill $20-30 \%$ of its domestic demand [4].

One of the problems faced in handling subclinical mastitis lies on the ability to diagnose in the field and

Corresponding author: Herwin Pisestyani, DVM, research field: veterinary public health. the farmers accessibility to obtain a subclinical mastitis diagnosis kit. These conditions are also faced by the livestock in West Java with business scale of 5.8 heads per business unit and production capability of approximately 11.6 liter/head/day [5]. Therefore a more practical alternative solution is needed, such as studying the predisposing factors that can be used as an indicator of subclinical mastitis.

An attempt to identify subclinical mastitis predisposing factors among others is to assess udder health. According to Blakely, J. [6], udder health of dairy cattle in relation to milk production is affected by the cows' physical condition, milking habits, body condition score and udder scoring. Udder scoring covers teats length, position of the front teat, front udder linkage, udder depth, rear udder height, middle ligament and position of rear teat [6]. Saragih, B. [7] stated that other than the anatomical factor of the udder, cleanliness of the floor, floor surface and hygienic milking of udder also affect udder health. Udder health 
can be achieved by maintaining personal hygiene, milking hygiene, good shed management, good milking management, vaccination program, and administrating antibiotic periodically [8].

BIF [9] assign a standard that average size teat length for both front teats of Frisian Holstein (FH) cow should be $6 \mathrm{~cm}$ in length and $2.9 \mathrm{~cm}$ in diameter, while the rear has an average size of $5 \mathrm{~cm}$ in length and 2.6 $\mathrm{cm}$ in diameter. Prihadi, S. [10] stated that Indonesian FH cow is different then it's origin, it has the ability to produce an average of 10 liter per day with 12-15 month calving interval and lactation period approximately 10 month or an average milk production of 2,500-3,000 liter per lactation. The average age of dairy cows first lambing is $2-2.5$ years and this is the first lactation period [11]. Lactation period is the period the cow produces milk between birth and dry period, therefore duration of lactation is between 8-10 months [2].

There have not been many studies of predisposing factors for subclinical mastitis in dairy cattle. Therefore this research is needed to know teat length and lactation period as one of the predisposition factor for subclinical mastitis in the livestock in KPSBU Lembang Bandung Regancy.

\section{Material and Methods}

\subsection{Time and Place of Research}

The research is conducted in the month of July-December 2012, on the livestock who are members of KPBSU Lembang in Sukajaya Village, District Lembang, Bandung Regency, West Java.

\subsection{Tools and Materials}

Tools used in this research are paddle, measuring tape $(\mathrm{cm})$, cloth and stationery. Materials used are IPB-1 reagent mastitis test and milk sample from each quarter.

\subsection{Research Method}

This research is a field study of subclinical mastitis cases. Data is obtained through research and interview. Interview is conducted to obtain information regarding farmer and cow in normal lactation condition. Farmers' information includes: name of farmer, village, and number of cow in a shed. Cow information includes: cow number, age and lactation period, and amount of milk production per day. Somatic Cell Count (JSS) testing is done by indirect method. The indirect method used is subclinical mastitis diagnosis using IPB-1 Mastitis Test reagent. Measuring the length of teats is done using tape measure expressed in centimeters $(\mathrm{cm})$.

\subsection{Determination of Sample Size and Withdrawal}

Determination of sample size begin with recording the number of dairy cattle in Sukajaya Village based on udder health testing requirements which are; cows is in its normal lactation condition. The amounts of sample size obtained are 72 dairy cows.

\subsection{Measuring of Teat Length}

Teat length is measured using measuring tape $(\mathrm{cm})$. Measuring is performed on each quarter after cow is bathed.

\subsection{Subclinical Mastitis Testing}

Subclinical mastitis testing is done by indirect method using IPB-1 Mastitis Test reagent [12]. Paddle is filled with $2 \mathrm{~mL}$ of milk from a cow that was previously bathed, udder cleaned, and then milk is milked from the teat. First and second spray is disposed, and then the next spray of milk is collected in the paddle. IPB-1 Mastitis Test reagent is added in the sample with a 1:1 ratio. Sample and reagent is homogenized horizontally for 15-30 s. Test principles of IPB-1 Mastitis Test is that the reagent will bind with somatic cell nucleus DNA which will form a think gelatin like mass. A thicker mass shows more somatic cell nucleus DNAs that are bind with IPB-1 Mastitis Test reagent.

Results interpretation. The reaction is observed according to Sudarwanto M. [1], if reaction is negative, milk and reagent stays homogeneous, if positive one it will form a thin mucous, positive two will form a 
thicker mucous, positive three mucous is very thick like a gelatin mass.

\subsection{Data Analysis}

Data is analyzed descriptively, Gamma test and logistic regression analysis. Descriptive analysis and Gamma test is used to see relation or correlation between variables in the study and to determine the association variables that are ordinal [13]. Data is also analyzed by using Microsoft Office Excel 2007 and Duncan test.

\section{Result and Discussion}

\subsection{Influence of Teat Length Towards the Severity of Subclinical Mastitis}

Udder or cows mammary gland consist of 4 separate parts. The left and right part is separated by a sulcus called sulcus intermamaria that runs longitudinally. Aspects that must be observed from the udder are size, production capacity, udders' height from floor surface when cow is standing, and udder symmetry [14].

Ligamentum suspensorium is the divider from each udder quarter. This ligament functions as a foundation for the udder and a divider between quarters. The outer ligament is the Ligamentum lateralis [15]. This ligament functions as a buffer and gives the shape of the udder. Age can affect the strength of the ligament, which separates each quarter of the udder. The higher the lactation period shows the older the age of the cow. Average teat lengths of each lactation period of dairy cattle in KPSBU Lembang Bandung Regency are shown in Table 1.

Results of this study show an increase of teat length in each lactation period. In the first lactation period teat length is $4.75 \mathrm{~cm}$, second lactation $5.6 \mathrm{~cm}$, third lactation $6.5 \mathrm{~cm}$, forth lactation $7.5 \mathrm{~cm}$, fifth lactation $7.6 \mathrm{~cm}$, and sixth lactation $8 \mathrm{~cm}$. Teats that become longer is influenced by incorrect ways of milking and weakness of ligament.

Traditional milking by using two fingers (Strip Method) will affect the anatomical shape of the udder.
Table 1 Average of teat length in each period of lactation of dairy cattle in KPSBU Lembang, Bandung Regency.

\begin{tabular}{llll}
\hline \multirow{2}{*}{ Lactation } & \multicolumn{3}{l}{ Teat length $(\mathrm{cm})$} \\
\cline { 2 - 4 } & average & $\min$ & $\max$ \\
\hline 1 & 4.75 & 3.75 & 5.0 \\
2 & 5.6 & 5.0 & 6.2 \\
3 & 6.5 & 6.0 & 6.9 \\
4 & 7.5 & 7.1 & 7.5 \\
5 & 7.6 & 7.2 & 7.8 \\
6 & 8 & 7.5 & 8.3 \\
\hline
\end{tabular}

Milking with two fingers is milking with the thumb and forefinger that shifts from the base of the teat down while messaging, loosen and tighten to the top. The weakness of milking this way is that the teat and udder are always wet, this can cause lesion on the udder and can slowly change the anatomical shape of the teat to become longer [16]. This method of milking is applied on farms in KPSBU Lembang. Udder with weak ligaments will show an udder shape that falls and hangs. Weak Ligamentum suspensorium will cause the udder to loose shape and loose its fold between quarters. Weakness of this ligament also causes the cows' teat to be prominent and long [15]. This study also shows the influence of teat length towards the degree of severity of subclinical mastitis from KPSBU Lembang dairy farm that is presented in Table 2 .

Data obtain from this study indicates that teat length significantly affects the level of severity of subclinical mastitis $(P<0.05)$. Table 2 shows that teat with a 7.5 $\mathrm{cm}$ length is more susceptible to subclinical mastitis compared to teat with a $4.75 \mathrm{~cm}$ length, therefore teat length can be used as a predisposing factor of

Table 2 Influence of teat length towards the degree of severity of subclinical mastitis from KPSBU Lembang Bandung Regency.

\begin{tabular}{llll}
\hline Degree of & \multicolumn{3}{l}{ Teat length $(\mathrm{cm})$} \\
\cline { 2 - 4 } Severity of MSK & average & $\min$ & $\max$ \\
\hline- & $4.75^{\mathrm{a}}$ & 3.75 & 5.5 \\
+ & $5.75^{\mathrm{a}}$ & 5.5 & 6 \\
++ & $6.5^{\mathrm{b}}$ & 6 & 7 \\
+++ & $7.5^{\mathrm{c}}$ & 7 & 8.3 \\
\hline
\end{tabular}

Description:*subclinical mastitis; different superscript letter in the same column followed by the same letter are not significantly different at the test level of $P<0.05$. 
subclinical mastitis. Teat with a $7.5 \mathrm{~cm}$ length has a level of subclinical mastitis severity of positive $3(+++)$, teat with a $6.5 \mathrm{~cm}$ has a level of subclinical mastitis severity of positive $2(++)$, and teat with a $5.75 \mathrm{~cm}$ has a level of subclinical mastitis severity of positive $1(+)$. Teat condition that does not have subclinical mastitis is shown by teat that has a length of $4.75 \mathrm{~cm}$. According to the result of the study, farmers can use teat length as a diagnosis indicator for subclinical mastitis that is dairy cattle with teat length of $6.5-7.5 \mathrm{~cm}$ may have subclinical mastitis.

BIF [9] stated that subclinical mastitis cases occur in teats with a length category of 7-9 $\mathrm{cm}$. Subronto [2] stated udders that hangs tremendously or udders that are long and have large teat opening is a predispose factor to udder inflammation in terms of the cattle. Long teats will make it easy for microbes to enter the internal tissue of the udder from the outside of the teat through the teat hole (ascendens) and lesions on the udder due to friction with the floor [16]. Teat size that are to short is also a predispose factor for subclinical mastitis. This is because farmers have difficulty in milking therefore the alveoli cannot secrete milk completely.

\subsection{Influence of Lactation Period towards Severity Level of Subclinical Mastitis}

Mastitis is an inflammation of the udder, whether it is acute, sub acute or chronic, with the increase of somatic cells in the milk and physical as well as the composition of milk, with or without pathological changes in the gland [2]. 95-98\% of mastitis incidence is subclinical mastitis, while $2-3 \%$ incidence of clinical mastitis is detected [1]. Losess caused by subclinical mastitis are decreased in milk production, decreased of milk quality, expensive cost for treatment and medication, early culling of cattle as well as purchasing of new dairy cattle [2].

Length of the teat, ligament linkage, feed, weather, lactation period and genetic quality of the cow can influence subclinical mastitis [17]. The influence of lactation period towards the degree of severity of subclinical mastitis in dairy cattle in KPSBU Lembang is presented in Figure 1.

This study shows that lactation period significantly affects the degree of severity of subclinical mastitis $(P$ $<0.05)$, meaning that the higher the lactation period will increase the degree of severity of subclinical mastitis. Base on Figure 1 it appears that the incidence of subclinical mastitis with different degree of severity has increased on each lactation period. For cows in its first lactation, age between 2.5-3 years and its first time giving birth, shows that the presentation of subclinical mastitis incidence with a degree of severity ranging between $0.7 \%-1.7 \%$. Incidence of subclinical mastitis with a positive three degree of severity continues to increase until its peak that is at the forth lactation period as high as $8.3 \%$. This is likely due to cows that previously experienced subclinical mastitis with a degree of severity of 1 and 2 whom later became worse and became a positive 3 . In cows that have reached the fifth and sixth lactation period with age range of 8-9 years, it is seen that the degree of severity of subclinical mastitis of positive three experience a decrease. Cows that initially experienced subclinical mastitis but because they were not handled well became a clinical mastitis case may have caused this. The decrease of percentage of positive 3 degree of severity of subclinical mastitis can also be due to healing process because of

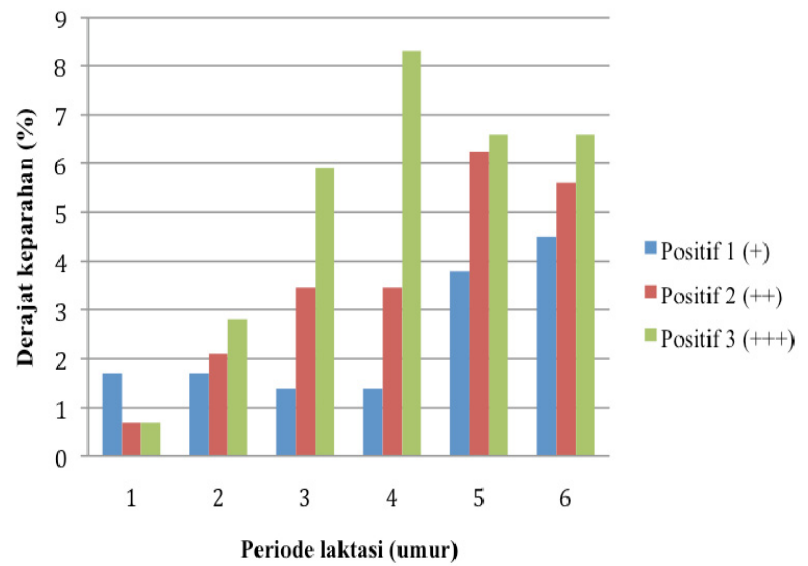

Fig. 1 Influence of lactation period towards the degree of severity of subclinical mastitis in KPSBU Lembang Bandung Regency. 

Mastitis in Dairy Cattle in Bandung, Indonesia

good handling. This study is consistent to [18] study that stated that subclinical mastitis incidence will increase until cow reaches the age of around eight years and will continue to increase from the first lactation until its peak that is in the third and forth lactation period which will then decrease according to the next lactation period.

Increase of subclinical mastitis incidence may occur because the older the cow becomes the udders main supporting tissue that is Ligamentum suspensatorium lateral et medial weakens and nutrition that is given to the cow lacks guarantee which can lead to clinical mastitis incidence [15]. The increase of lactation period will cause the time needed for teat cistern to close longer which will facilitate the entrance of microorganisms from outside into the udder. Age factor and degree of milk production of cow also affects the incidence of mastitis. The older the cow and the higher its milk production, the more loose the teat sphincter is. Teat with a loose sphincter will enable the cow to be infected with microorganism. The more a cow produces milk; therefore the longer time is needed for the sphincter to close completely [2].

\subsection{Correlation between Teat Length and Lactation} Period with Degree of Incidence of Subclinical Mastitis

Subclinical mastitis causes loss milk production up $70 \%$ per head [1]. In the practices of dairy farming, it is known that the correlation between lactation periods, teat length with subclinical mastitis cannot be separated from the affects of early selection [19]. Correlation between teat length and lactation period with subclinical mastitis incidence of dairy farms in KPSBU Lembang is presented in Figure 2.

Figure 2 shows a linear correlation between teat length and lactation period towards degree of incidence of subclinical mastitis in KPSBU Lembang. This means there is a significant correlation between teat length and lactation period towards degree of incidence of subclinical mastitis. Higher lactation period and longer teats will increase the percentage of subclinical mastitis incidence. In the first lactation period, cows with teat length of $4.75 \mathrm{~cm}$ experience subclinical mastitis incidence as high as $45 \%$. Percentage of subclinical mastitis incidence as high as $48 \%$ occur in cows with teat length of $6.5 \mathrm{~cm}$ and has entered the third lactation period. Cows that has entered the fifth and sixth lactation period with teat length of $7.6 \mathrm{~cm}$ and $8 \mathrm{~cm}$ has a $60 \%$ and $70 \%$ chance of being affected by subclinical mastitis. From this study it is obtained that teat length and lactation period can be used as diagnosis indicator of subclinical mastitis and can also be used as a predisposed factor from subclinical mastitis incidence.

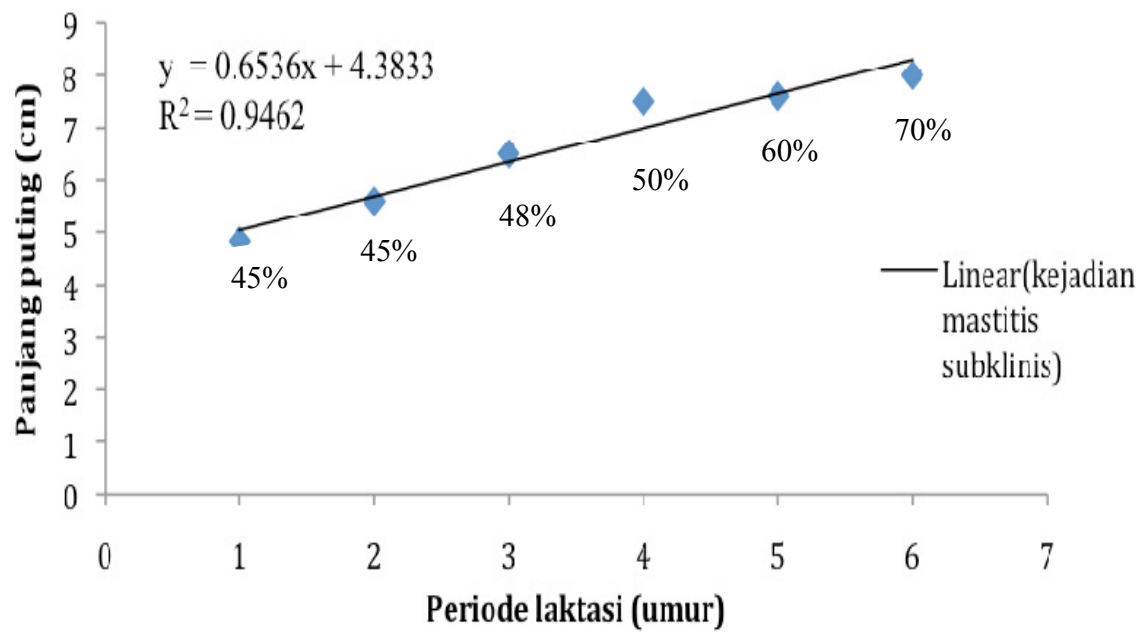

Fig. 2 Correlation between lactation period and teat length with subclinical mastitis incidence in KPSBU Lembang Bandung Regency $(r=0.972, P<0.05)$. 
This study is consistent with [20] that stated higher lactation period and longer teat length will cause the degree of incidence of subclinical mastitis to increase. This is due to weakness of ligament in maintaining the anatomical shape and the closing of the teat sphincter which need longer time. Sudarwanto M. [1] stated that time needed for the teat sphincter to close or restore of teat width after milking is $10-15 \mathrm{sec}$. The more time the sphincter needs to close, causes more amounts of microorganisms form the environment to enter the udder. One of the preventive measures to suppress the incidence of subclinical mastitis is teat dipping. Teat dipping is dipping of teats after milking into a liquid that contains disinfectant. Disinfectant used is iodophore with a $1 \%$ iodine concentration [15].

\section{Conclusions}

Lactation period and length of udder is a predisposing factor towards the level of incidence of subclinical mastitis in dairy cattle. Highest incidence of clinical mastitis occurred to dairy cattle with average teat length of $7.5 \mathrm{~cm}$ and was on the third and forth lactation period.

\section{References}

[1] Sudarwanto M. 1999. Usaha peningkatan produksi susu melalui program mastitis subklinis. Orasi Ilmiah. Bogor, 22 Mei 1999.

[2] Subronto. 2003. Ilmu Penyakit Ternak 1. Yogyakarta (ID): UGM Pr.

[3] DSSP (Data Sementara Statistik Peternakan). 2009. Produksi Susu Sapi Perah. [Internet]. [diacu 2013 April 17]. Tersedia dari: http://faterna.unand.ac.id/index.php? tabel=1\&id_subyek=36.

[4] Luthan, F. 2011. Pengembangan Agribisnis Persusuan di Indonesia. Sumatera Barat (ID): Universitas Andalas.

[5] DSSP (Data Sementara Statistik Peternakan). 2008. Produksi Susu Sapi Perah. [Internet]. [diacu 2013 April 17]. Tersedia dari: http://faterna.unand.ac.id/index.php? tabel=1\&id_subyek=36.

[6] Blakely, J., and Bade, D. H. 1991. Ilmu Peternakan. Ed ke-4. Terjemahan: Srigandono B. Yogyakarta (ID): UGM Pr.

[7] Saragih, B. 2000. Kumpulan Pemikiran: Agribisnis Berbasis Peternakan. Bogor (ID): Pustaka Wirausaha Muda.

[8] Alluwaimi, A. M. 2004. The Cytokines of Bovine Mammary Gland: Prospect for Diagnosis and Therapy. Research in Veterinary Science (in Pr).

[9] BIF (Beef Improvement Federation). 2011. BIF Guidelines for Unifrom Beef Improvement Program. 8th ed. Beef Improvement Federation. Athens (GR): Georgia Univ.

[10] Prihadi, S. 1997. Dasar Ilmu Ternak Perah. Yogyakarta (ID): Fakultas Peternakan Universitas Gajah Mada.

[11] Sudono, A. 1999. Ilmu Produksi Ternak Perah. Diktat Kuliah Fakultas Peternakan IPB, Bogor. Jurusan Ilmu-ilmu Sosial Ekonomi Pertanian. Bogor (ID): Fakultas Pertanian IPB.

[12] Sudarwanto M. 1998. Pereaksi IPB-1 sebagai pereaksi alternatif untuk mendeteksi mastitis subklinis. Bogor (ID): Fakultas Kedokteran Hewan Institut Pertanian Bogor.

[13] Agresti, A., and Finlay, B. 2009. Statistical Methods for the Social Science. New Jersey (US): Pearson E.

[14] Farmer, W. S., and Chrestman, G. 2006. Dairy Cattle Judging. Mississipi (US): Mississipi State University.

[15] Falvey, L., and Chantalakhana, C. 1999. Smallholder Dairying in the Tropics. Bibliography: Milking, chapter 16. Nairobi. Kenya (KE): Internasional Livestock Research Institute.

[16] Lukman, D. W., Sudarwanto, S., Sanjaya, A. W., Purnawarman, T., Latif, H., Soejoedono, R. R., and Pisestyani, H. 2009. Higiene Pangan. Bagian Kesehatan Masyarakat Veteriner Departemen Ilmu Penyakit Hewan dan Kesmavet. Bogor (ID): Fakultas Kedokteran Hewan Institut Pertanian Bogor.

[17] Ikawati, A. 2011. Analisis kandungan protein dan lemak susu hasil pemerahan pagi dan sore pada peternakan sapi perah di Wonocolo Surabaya [skripsi]. Surabaya (ID): Fakultas Kedokteran Hewan Universitas Airlangga.

[18] Siregar, S. 1995. Jenis Teknik Pemeliharaan dan Analisa Usaha Sapi Perah. Jakarta (ID): Penebar Swadaya.

[19] Lush, S. 1990. "Jenetic Progress trough Selection in a Closed Herd of Indian Cattle." J. Dairy Sci. 51: 1059-64.

[20] Sudono, A., Rosdiana, R. F., and Setiawan, B. S. 2003. Beternak Sapi Perah Secara Intensif. Jakarta (ID): Agromedia Pustaka. 